\title{
Composition of tocopherols in sesame seed oil: an indicative of adulteration
}

\author{
By Sabria Aued-Pimentel ${ }^{1 *}$; Emy Takemoto'; Rosemar Antoniassi ${ }^{2}$ and Elza S. Gastaldo \\ Badolato ${ }^{1}$ \\ ${ }^{1}$ Instituto Adolfo Lutz, Divisão de Bromatologia e Química; C. P. 1783, zip code 01059-970 \\ São Paulo, SP, Brazil. \\ ${ }^{2}$ EMBRAPA - Agroindústria de Alimentos - Rio de Janeiro, RJ, Brazil \\ ${ }^{*}$ Corresponding author: E-mail sabria_aued @ial.sp.gov.br
}

\section{RESUMEN}

Composición de tocoferoles en aceite de semilla de sésamo: indicativo de adulteración

Este trabajo examina la importancia de los tocoferoles en la detección de la adulteración del aceite de sésamo comercializado en Brasil. Se analizaron cinco muestras a las que se le determinaron su composición en ácidos grasos, esteroles y tocoferoles. Una de las muestras se reveló puro aceite de semilla de sésamo; en otra, todos los parámetros estaban en desacuerdo. En las demás, el perfil de ácidos grasos caracterizaba el aceite de sésamo, sin embargo los tocoferoles y esteroles permanecieron en desacuerdo. Los resultados indican adulteración con otros aceites vegetales como soja, aceites láuricos y maíz.

PALABRAS-CLAVE: Aceite de semilla de sésamo Adulteración - Composición de tocoferoles.

\section{SUMMARY}

Composition of tocopherols in sesame seed oil: an indicative of adulteration

The objective of this research was to verify how the composition of tocopherols can help to reveal adulteration in samples of sesame seed oils commercialized in Brazil. Five samples have been analyzed. One sample presented the composition of fatty acids, tocopherols and desmethylsterols of authentic sesame oil. Another one presented only non complying parameters. Three other samples showed the fatty acid composition of pure sesame oil, but the tocopherol and desmethylsterol profiles did not comply with those for sesame seed oil. The results indicate that samples could be adulterated by other vegetable oils like soybean, lauric and corn oils.

KEY-WORDS: Adulteration - Sesame seed oil Tocopherol composition.

\section{INTRODUCTION}

The diversity of edible oils and fats has been growing all over the world. The search for new oleaginous seeds and the contributions of technological and biotechnological processes have promoted improvements in quantity and quality of fats and seeds but can alter the composition of the original food nutrients (Euro alert, 2000). Food authenticity is an important topic in both a commercial and a health point of view. Nowadays consumers are more demanding and conscious about their rights and the benefits food nutrients should provide to human health. These subjects have generated more studies to increase the knowledge of chemistry, composition and structure of oils and fats and therefore, a better characterization of them. The determination of the triacylglycerols and the minority components of the unsaponifiable fraction of vegetable oils, applying more sensitive and precise analytical techniques has aided in determining the quality and authenticity of those products (Aparicio and Aparicio-Ruiz, 2000; Aparicio, 2003; Cert et al., 2000)

In Brazil there has been a high incidence of adulteration in vegetable oils, mainly in olive oil and other imported oils of high commercial value, and sesame oil is included in this category (Antoniassi et al., 1988; Aued-Pimentel et al., 1993; Aued-Pimentel et al., 2002; Badolato et al., 1981). The assessment of the identity of vegetable oils has been made by the composition of fatty acids and some classic parameters such as the iodine value and refractive index, and in many cases these are not enough to detect more elaborated frauds in vegetable oils. Determination of the desmethylsterol and fatty acid composition comprehend official methodologies to define the identity of edible vegetable oils (AOAC 1995; IUPAC 2.403, 1992). Antoniassi et al. (1998), to evaluate both quality and identity of olive oil samples marketed in Brazil, verifying that only the desmethylsterol composition provides the distinction and definition of identity and quality of the samples.

Several authors have pointed out the composition of the tocopherols and tocotrienols in vegetable oils as a good parameter to aid in the identification and differentiation of them (Aparicio and Aparicio-Ruiz, 2000). Gutfinger and Letan (1974) detected, through the determination of the tocopherol composition, the addition of soybean oil in olive oil samples. Soybean oil is rich in delta and gamma tocopherols while olive oil presents significant amounts of alpha-tocopherol. Dionisi et al. (1995) used HPLC with amperometric detector to determine the tocopherol and tocotrienol composition in vegetable oils and detected small quantities ( 1 to 
$2 \%$ ) of palm and grape seed oils in olive oil. Mariani et al. (1999) employed tocopherol composition to investigate the addition of hazelnut oil in olive oil samples.

Tocopherols are natural antioxidants that inhibit oil oxidation. Tocopherols act as biological kidnappers of free radicals and could prevent diseases, besides possessing an important nutritional function for human beings as a source of Vitamin E (BrigeliusFlohe et al., 2002; Monahan et al., 1993). The objective of this paper is to determine the composition of tocopherols in sesame oils commercialized in Brazil and verify if this can indicate frauds or alterations in those vegetable oils, along with fatty acid and desmethylsterol composition.

\section{MATERIAL AND METHODS}

\subsection{Samples, standards and reagents}

Five (5) samples of sesame seed oil commercialized in Brazil have been analyzed.

Alpha, beta, gamma and delta high purity tocopherol standards were purchased from Merck. A mixture of fatty acid methyl ester standards from $\mathrm{C}_{4}$ to $\mathrm{C}_{24}$ with certificate of composition was purchased from Supelco Park (Bellefonte, PA, USA). Desmethylsterol standards were purchased from Sigma Chemical (Saint Louis, USA). Methanol, nhexane, isopropanol (HPLC grade) were obtained from EM Science (USA). All other solvents and chemicals had reagent grade.

\subsection{Methods}

\subsubsection{Composition of tocopherols}

Tocopherols were separated and quantified by HPLC, according to AOCS Ce 8-89 methodology. Oil was dissolved in $\mathrm{n}$-hexane and submitted directly to HPLC analysis. A system of liquid chromatography from Shimadzu was used, composed by the modules: bomb LC-10AD; Rheodyne Injector with a $20 \mathrm{~mL}$ loop, fluorescence detector (RF-10AXL) with wavelengths of excitation at $290 \mathrm{~nm}$ and of emission at $330 \mathrm{~nm}$; communication module CBM-10-AD and software Class LC10-AD for data storing and total control of the system.

The components were separated in a normal phase chromatographic column SI 60, $5 \mu \mathrm{m}, 250 \mathrm{x}$ $4.6 \mathrm{~mm}$ id purchased from SGE Analytical Products. The mobile phase was $1.2 \mathrm{~mL} / \mathrm{min}$ flow $\mathrm{n}$ hexane/isopropanol (99.5:0.5 V/V). The solvents used had HPLC grade. The mobile phase was filtered through $0.45 \mu \mathrm{m}$ membrane and degassed with helium gas for 15 minutes in a degasser on line with the chromatograph (Model DGU-14 Shimadzu). Oils were diluted in $\mathrm{n}$-hexane to obtain a concentration of about $8 \mathrm{mg} / \mathrm{mL}$ and filtrated through a $0.45 \mu \mathrm{m}$ membrane and injected into the chromatograph. Samples were analyzed three times.
Tocopherols were quantified by external standard with alpha, beta, gamma and delta tocopherols, high purity standards (Merck). Standards' purity was monitored by measures of $E^{1 \%} \mathrm{~cm}$ in methanol in an HP 8453 spectrophotometer.

Tocopherols were identified by co-injection of tocopherol standards by comparison of the retention times and through the addition of standards in the samples. Quantification was performed by plotting calibration curves from tocopherol standards and comparing the peak area of the correspondent peaks in samples.

\subsubsection{Composition of fatty acids}

Fatty acid methyl esters were prepared by an acid catalyzed procedure. About $25 \mathrm{mg}$ of oil sample was weighed into a transmethylation flask and 15 $\mathrm{mL}$ of a methanol solution with $2 \% \mathrm{H}_{2} \mathrm{SO}_{4}$ and $3 \mathrm{~mL}$ of $n$-hexane were added. The sample was refluxed for 45 minutes. A saturated solution of $\mathrm{NaCl}$ was added to separate the phases (Instituto Adolfo Lutz, 2004; Badolato and Almeida, 1977). The upper phase $(1 \mu \mathrm{L})$ was analyzed in a GC-17A Shimadzu model gas chromatograph equipped with a flame ionization detector. The compounds were separated in a $50 \mathrm{~m} \mathrm{CP-Sil} 88$ capillary fused silica column, $0.25 \mathrm{~cm}$ internal diameter and $0.20 \mathrm{~mm}$ film thickness. Operation conditions were as follows: oven temperature 80 to $220^{\circ} \mathrm{C}\left(5^{\circ} \mathrm{C} / \mathrm{min}\right)$; injector temperature, $230^{\circ} \mathrm{C}$; detector temperature, $240^{\circ} \mathrm{C}$; carrier gas: hydrogen; gas linear velocity 40 $\mathrm{mL} / \mathrm{min}$; ratio of sample division, 1:50. Fatty acid methyl esters were identified by co-injection of the standards. Quantification was performed by area normalization.

\subsubsection{Composition of desmethylsterols}

The unsaponifiable matter of oils was separated following AOCS method Ca-6b-53, 1997. Thin layer chromatography was used to fractionate the unsaponifiable matter in accordance to IUPAC method 2.403. The desmethylsterol fraction was submitted to gas chromatography. The components were separated by capillary fused column of methylsilicone (HP-1) of $25 \mathrm{~mm}$ length, $0.32 \mathrm{~mm}$ internal diameter and film thickness of $0.17 \mu \mathrm{m}$. The analysis was made with the oven temperature at $260^{\circ} \mathrm{C}$ to $290^{\circ} \mathrm{C}\left(3^{\circ} \mathrm{C} / \mathrm{min}\right)$; injector temperature, $300^{\circ} \mathrm{C}$; detector temperature, $300^{\circ} \mathrm{C}$. The components were identified by co-injection of standards and by comparison of sesame and sunflower oils obtained from seeds and authentic olive oil analyzed at the same time. Quantification was performed by area normalization.

\section{RESULTS AND DISCUSSION}

Tables 1, 2 and 3 present, respectively, the composition of tocopherols, fatty acids and desmethylsterols obtained in commercial sesame 
Table 1

Composition of tocopherols in vegetable oils samples ( $\mathrm{mg} / 100 \mathrm{~g}$ of oil)

\begin{tabular}{|c|c|c|c|c|}
\hline Tocopherols & Alpha & Beta & Gamma & Delta \\
\hline $\begin{array}{l}\text { Sample A * } \\
\text { Commercial sesame seed oil }\end{array}$ & $2.4 \pm 0.1$ & $0.28 \pm 0.04$ & $42 \pm 1$ & $0.71 \pm 0.04$ \\
\hline $\begin{array}{l}\text { Sample } B^{\star} \\
\text { Commercial sesame seed oil }\end{array}$ & $36 \pm 2$ & $0.80 \pm 0.04$ & $16 \pm 3$ & $0.17 \pm 0.05$ \\
\hline $\begin{array}{l}\text { Sample } C^{*} \\
\text { Commercial sesame seed oil }\end{array}$ & $0.24 \pm 0.05$ & $0.38 \pm 0.09$ & $57 \pm 4$ & $0.91 \pm 0.06$ \\
\hline $\begin{array}{l}\text { Sample } D^{*} \\
\text { Commercial sesame seed oil }\end{array}$ & $19 \pm 2$ & $0.58 \pm 0.06$ & $38 \pm 3$ & $13 \pm 2$ \\
\hline $\begin{array}{l}\text { Sample } E^{\star} \\
\text { Commercial sesame seed oil }\end{array}$ & $7.4 \pm 0.1$ & $0.8 \pm 0.2$ & $25 \pm 1$ & $0.79 \pm 0.03$ \\
\hline Sunflower ** & $40.3-93.5$ & ND -4.5 & ND-3.4 & ND-0.7 \\
\hline Sesame ** & ND- 0.33 & ND & $52.1-98.3$ & $0.4-2.1$ \\
\hline Soybean** & $0.9-35.2$ & ND-3.6 & $8.9-230.7$ & $15.4-93.2$ \\
\hline Corn ${ }^{\star *}$ & $2.3-57.3$ & ND-35.6 & $26.8-246.8$ & $2.3-7.5$ \\
\hline
\end{tabular}

*Mean and standard deviation of three determinations.

** Codex Stan 210, 1999.

ND - Non detectable

oil samples, codified as A, B, C, D and E. Tables 1, 2, 4 and 5 present reference values for tocopherols, fatty acids and sterols from literature.

All samples presented percentages of some fatty acids different from values referred by Codex Alimentarius (1999), but samples B and E are in compliance with AOCS ranges (Firestone, 1999). The fatty acid composition of 721 from different samples of sesame seed oil obtained on a worldwide basis by Yermanos et al. (1972) was presented in Table 2 and these values differed markedly from the ranges of AOCS (Firestone, 1999) and Codex Alimentarius (1999). The fatty acid profiles of samples $A, B$ and $E$ are in compliance with reported values by Yermanos et al. (1972). The fatty acid profile of sample $\mathrm{C}$ was in compliance with that range, except for palmitic acid, which was just a little below.

At the same time, considerable differences were observed among the relative proportions of desmethylsterols of sesame seed oil from the literature (Table 4). The ranges reported by Codex Alimentarius (1999) and AOCS (Firestone, 1999) are not comparable with profiles of desmethylsterols of sesame (Sesamun indicum) from Sudan (Kamal Eldin et al., 1992, 1994b) and samples of sesame oil from Central Africa, Egypt, Nigeria, Sudan and Mexico reported by Bocca et al. (1988). The high percentage of $\Delta^{7}$-stigmastenol and $\Delta^{7}$-avenasterol reported by Codex and AOCS are common to sunflower (Helianthus annuus L.) and safflower oils (Carthamus tinctorius L.).

Table 2

Fatty acid composition of sesame seed oil samples (expressed as percentage of total fatty acids)

\begin{tabular}{|c|c|c|c|c|c|c|c|c|c|c|c|c|c|c|c|c|}
\hline $\begin{array}{l}\text { Fatty acid } \\
\text { samples }\end{array}$ & C8:0 & $\mathrm{C} 10: 0$ & C12: 0 & C14:0 & $\mathrm{C} 16: 0$ & C16:1 & C17:0 & C18:0 & C18:1 & $\begin{array}{l}\text { C18:2 } \\
\text { cis }\end{array}$ & $\begin{array}{l}\mathrm{C} 18: 2 \\
\text { trans }\end{array}$ & $\begin{array}{l}\text { C18:3 } \\
\text { cis }\end{array}$ & $\mathrm{C} 20: 0$ & C20:1 & C22:0 & C24:0 \\
\hline Sample A & - & - & - & - & 9.97 & 0.11 & 0.08 & 6.09 & 34.93 & 46.96 & 0.59 & 0.31 & 0.56 & 0.16 & 0.10 & 0.11 \\
\hline Sample B & - & - & - & - & 9.77 & - & 0.09 & 4.55 & 38.13 & 46.23 & - & 0.39 & 0.44 & 0.17 & 0.07 & 0.15 \\
\hline Sample C & - & - & - & - & 7.38 & 0.13 & 0.12 & 4.18 & 39.68 & 47.19 & 0.16 & 0.31 & 0.34 & 0.16 & 0.29 & 0.10 \\
\hline Sample D & 038 & 0.33 & 5.10 & 1.77 & 15.00 & - & 0.10 & 1.90 & 28.59 & 42.49 & - & 3.49 & 0.28 & 0.22 & 0.16 & 0.23 \\
\hline Sample E & & & & & 9.14 & 0.14 & 0.07 & 5.32 & 42.78 & 40.87 & & 0.51 & 0.55 & 0.26 & 0.12 & 0.22 \\
\hline $\begin{array}{l}\text { Codex Stan } 210 \\
\text { (1999) }\end{array}$ & & & & $\begin{array}{l}\mathrm{ND}- \\
0.1\end{array}$ & $\begin{array}{l}7.9- \\
12.0\end{array}$ & $\begin{array}{l}0.1- \\
0.2\end{array}$ & $\begin{array}{l}\text { ND- } \\
0.2\end{array}$ & $\begin{array}{l}4.8- \\
6.1\end{array}$ & $\begin{array}{l}35.9- \\
42.3\end{array}$ & $\begin{array}{l}41.5- \\
47.9\end{array}$ & - & $\begin{array}{l}0.3- \\
0.4\end{array}$ & $\begin{array}{l}0.3- \\
0.6\end{array}$ & $\begin{array}{l}\mathrm{ND}- \\
0.3\end{array}$ & $\begin{array}{l}\mathrm{ND}- \\
0.3\end{array}$ & $\begin{array}{l}\mathrm{ND}- \\
0.3\end{array}$ \\
\hline Firestone (1999) & & & & $\begin{array}{l}N D- \\
0.1\end{array}$ & $\begin{array}{l}7.9- \\
12.0\end{array}$ & & $\begin{array}{l}\mathrm{ND}- \\
0.2\end{array}$ & $\begin{array}{l}4.4- \\
6.1\end{array}$ & $\begin{array}{l}33.5- \\
44.1\end{array}$ & $\begin{array}{l}40.3- \\
50.8\end{array}$ & - & $\begin{array}{l}0.3- \\
0.5\end{array}$ & $\begin{array}{l}0.3- \\
0.7\end{array}$ & $\begin{array}{l}\mathrm{ND}- \\
0.3\end{array}$ & $\begin{array}{l}\mathrm{ND}- \\
0.3\end{array}$ & $\begin{array}{l}\mathrm{ND}- \\
0.3\end{array}$ \\
\hline $\begin{array}{l}\text { Yermanos et al } \\
\text { (1972) }\end{array}$ & & & & & $\begin{array}{l}8.3- \\
10.9\end{array}$ & & & $\begin{array}{l}3.4- \\
6.0\end{array}$ & $\begin{array}{l}32.7- \\
53.9\end{array}$ & $\begin{array}{l}39.3- \\
59.0\end{array}$ & & & & & & \\
\hline
\end{tabular}

*Mean of two determinations.

ND - Non detectable, defined as $\leq 0.05 \%$ 
Table 3

Composition of desmethylsterols in sesame seed oil samples (expressed as percentage (\%) of total desmethylsterols)

\begin{tabular}{lccccc}
\hline Desmethysterol & Sample A & Sample B & Sample C & Sample D & Sample E \\
\hline Campesterol & 15.83 & 13.22 & 18.57 & 14.94 & 21.42 \\
Stigmasterol & 6.40 & 6.43 & 6.41 & 12.36 & 5.39 \\
$\beta$-sitosterol & 57.58 & 64.28 & 59.15 & 54.30 & 57.23 \\
$\Delta^{5}$-avenasterol & 17.22 & 5.77 & 12.36 & 6.47 & 6.14 \\
$\Delta^{7}$-stigmastenol & ND & 7.43 & 0.24 & 5.33 & 0.68 \\
$\Delta^{7}$-avenasterol & 0.82 & 2.87 & 0.86 & 3.06 & 0.76 \\
Others & 2.15 & - & 2.41 & 2.53 & 8.36 \\
\hline
\end{tabular}

Sample A presented a desmethylsterol composition close to literature values for sesame oil (Table 3 and 4), except for the high content of $\Delta^{5}$ avenasterol. However, the alpha-tocopherol content in sample $A(2.4 \pm 0.1 \mathrm{mg} / 100 \mathrm{~g})$ was above the limit for sesame seed oil while gamma-tocopherol contents $(42 \pm 1 \mathrm{mg} / 100 \mathrm{~g})$ were below the reference values (Table 1).

The Alpha-tocopherol content of samples B and E was above and gamma-tocopherol below reference values (Table 1). The desmethylsterol composition of sample $\mathrm{B}$ showed that $\Delta^{7}$-stigmastenol percentage was above, and $\Delta^{5}$-avenasterol was below the expected values for sesame seed oil (Tables 3 and 4). The results suggest that sunflower oil was probably added to sample $B$.

It is well known that sesame oil contains natural antioxidants, as sesamin and sesamolin (lignans). These are characteristic components of sesame seed oil (Hemaltha and Ghafoorunissa, 2004) and are eluted and identified during HPLC analyses of tocopherols by the fluorescent detector (Antoniassi and Souza, 2001; Coors and Montag, 1985; KamalEldin, 1994a). In all samples, except in sample E, the chromatographic profile of tocopherols revealed the presence of peaks 2 and 5 in Figures $2 \mathrm{~A}$ and $2 \mathrm{~B}$, probably the lignans mentioned above.

The isolation, analysis and identification of sesamolin and sesamin from sesame seed oil along with desmethylsterol fraction had been carried out in previous investigations (Antoniassi et al., 2002a, b). The desmethylsterol fraction isolated by TLC analysis (70:30 petroleum ether/diethyl ether) was analysed by GC-MS. The analysis was performed on an Agilent 6890 chromatograph coupled with an Agilent 5973N mass spectrometer. Mass spectrum was obtained by electron impact ionization at $70 \mathrm{eV}$. Sesamolin and sesamin were detected in considerable amounts in the desmethylsterol fraction of sesame seed (Sesamun indicum), under these conditions. Figure 1 shows a desmethylsterol chromatogram of authentic sesame seed oil analyzed at the same time. The natural antioxidants co-eluted before the sterols are indicated in the chromatogram of Figure 1. They were not observed in sample $E$. The absence of these compounds can indicate that the sample was not sesame oil or it was submitted to a process that eliminated those compounds. Sample E presented an alphatocopherol content above $(7.4 \pm 0.1 \mathrm{mg} / 100 \mathrm{~g})$ and gamma-tocopherol $(25 \pm 1 \mathrm{mg} / 100 \mathrm{~g})$ below the ranges for sesame seed oil (Table 1). Fatty acid composition was inside the range referred to in the literature for corn oil and tocopherol contents were close to the values for this oil. The campesterol percentage stood above for sesame seed oil. The desmethylsterol profile of sample $E$ could be easily found in other vegetable oils, like corn oil (Table 5). The low contents of $\Delta^{7}$-stigmastenol and $\Delta^{3}$ avenasterol indicate that adulteration was probably not elaborated with sunflower oil. The results suggest that corn oil was the adulterant of sample $\mathrm{E}$.

The composition of fatty acids, tocopherols and desmethylsterols of sample $D$ were over the limit

Table 4

Composition of desmethylsterols of sesame seed oil (Sesamum indicum) (\%).

\begin{tabular}{|c|c|c|c|c|c|c|c|}
\hline & Campesterol & Stigmasterol & $\beta$-Sitosterol & $\begin{array}{c}\Delta^{5}- \\
\text { avenasterol }\end{array}$ & $\begin{array}{c}\Delta^{7} \text { - } \\
\text { stigmastenol }\end{array}$ & $\begin{array}{c}\Delta^{7}- \\
\text { avenasterol }\end{array}$ & Others \\
\hline $\begin{array}{l}\text { Codex Stan } 210 \\
\text { (1999) }\end{array}$ & $10.1-20.0$ & $3.4-12.0$ & $57.7-61.9$ & $6.2-7.8$ & $0.5-7.6$ & $1.2-5.6$ & $0.7-9.2$ \\
\hline Firestone (1999) & $10.1-20.0$ & $3.4-6,4$ & $57.7-61.9$ & $6.2-7.8$ & $1.8-7.6$ & $1.2-5.6$ & $0.7-9.2$ \\
\hline Bocca et al. (1988) & $17.6-20.2$ & $6.2-8.1$ & $53.0-60.4$ & 8.0-14.2 & $0.2-0.4$ & $0.4-0.8$ & - \\
\hline $\begin{array}{l}\text { Kamal-Eldin et al. } \\
\text { (1992) }\end{array}$ & $15.4-20.3$ & $5.4-8$ & $60.3-66.9$ & 6.4-10.6 & $0.8-2.7$ & 0.3-1.4 & - \\
\hline $\begin{array}{l}\text { Kamal-Eldin and } \\
\text { Appelqvist (1994) }\end{array}$ & $12.5-16.9$ & $6.0-8.7$ & $57.5-62.0$ & $8.1-11.5$ & $0.4-3.1$ & 0.3-1.3 & - \\
\hline
\end{tabular}




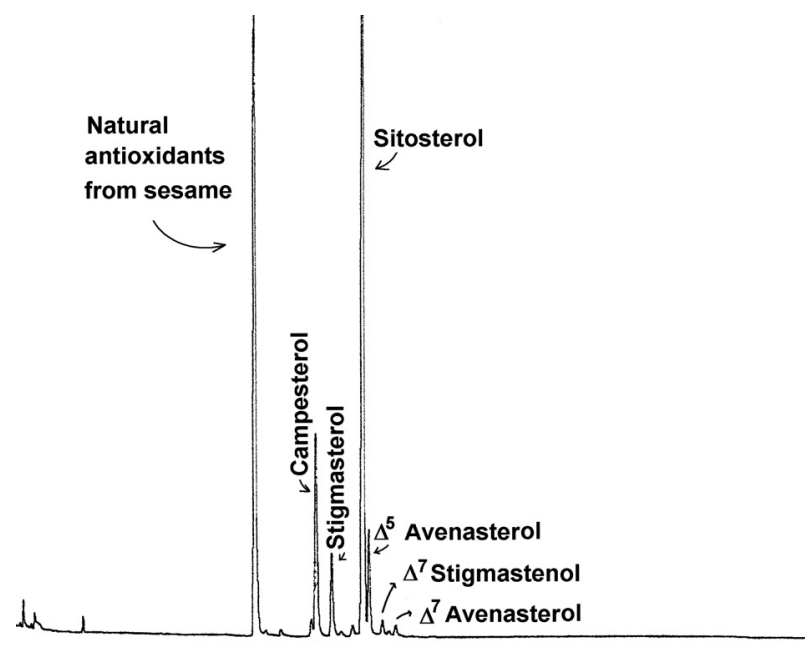

Figure 1

GC-FID desmethylsterols chromatogram of an authentic sesame seed oil

values referred to in the literature for sesame seed oil (Tables 1-4). The percentage of palmitic, linolenic, miristic and short-chain fatty acids (below $\mathrm{C}_{14: 0}$ ) were above the reference values for sesame seed oil (Table 2), while the percentage of oleic acid was below the expected. The quantity of linolenic acid found in sample D (3.5\%), could indicate the presence of canola or soybean oil. Regarding the composition of tocopherols, the contents of alpha and delta tocopherols found were above the values referred to for sesame oil (Table 1). Soybean oil presents quantities of those tocopherols similar to the values found in sample D. The content of campesterol was compatible with reference values for sesame seed oil and stigmasterol was above expected values (Tables 3 and 4). Soybean oil presents similar quantities of campesterol and stigmasterol which are higher than $15 \%$. Similar proportions of campesterol and stigmasterol were observed in sample $\mathrm{D}$, close to $15 \%$ (Table 3). The results indicate that the most probable alterations adulterants of sample $\mathrm{D}$ would be the addition of soybean and lauric oils.

Figure $2 \mathrm{~A}$ shows a chromatogram from pure sesame seed oil tocopherols; Figure 2B: sample D, probably adulterated with soybean oil; and Figure 2C: pure soybean oil.
Sample C showed fatty acid, desmethylsterols and tocopherol profiles close to the values from the literature for authentic sesame seed oil.

Briefly, the results showed that through fatty acid composition the adulteration of sesame oil was not conclusive, with the exception of sample D (inconclusive for D or only conclusive for D?). Considering the composition of tocopherol, the other three samples presented alteration in the profile for sesame oil (Samples A, B and E). The adulterations
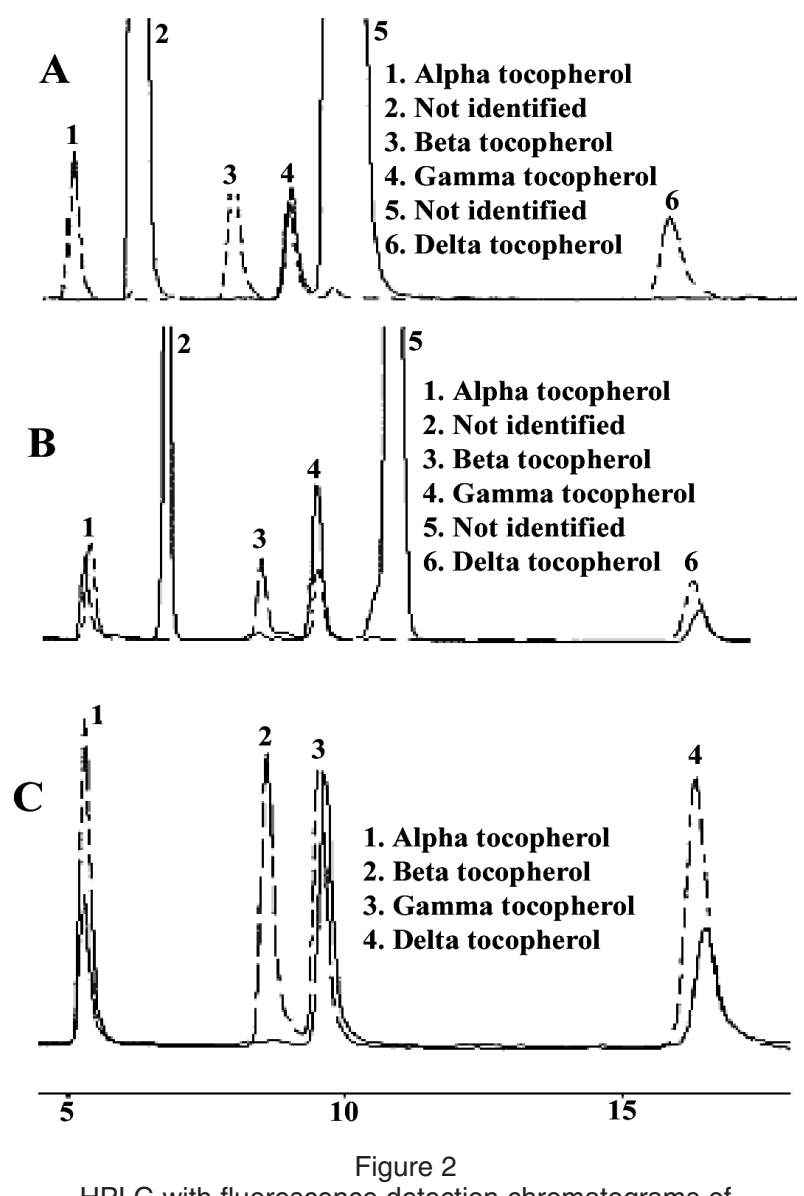

HPLC with fluorescence detection chromatograms of tocopherols in vegetable oils. A) Authentic sesame seed oil.

B) Authentic soybean oil C) Sesame seed oil probably adulterated with soybean oil (sample D).

- - - Tocopherol standards

------ Vegetable oil samples

Table 5

Composition of desmethylsterols in vegetable oils (\%)*

\begin{tabular}{lccc}
\hline Desmethylsterol & $\begin{array}{c}\text { Soybean oil } \\
\text { (Glycine } \text { max) }\end{array}$ & $\begin{array}{c}\text { Sunflower oil } \\
\text { (Helianthus annuus) }\end{array}$ & $\begin{array}{c}\text { Corn oil } \\
\text { (Zea mays) }\end{array}$ \\
\hline Campesterol & $15.8-24.2$ & $6.5-13.0$ & $16.0-24.1$ \\
Stigmasterol & $14.9-19.1$ & $6.0-13.0$ & $4.3-8.0$ \\
$\beta$-Sitosterol & $47.0-60.0$ & $50.0-70.0$ & $54.8-66.6$ \\
$\Delta^{5}$-avenasterol & $1.5-3.7$ & ND -6.9 & $1.5-8.2$ \\
$\Delta^{7}$-stigmastenol & $1.4-5.2$ & $6.5-24$ & $0.2-4.2$ \\
$\Delta^{7}$-avenasterol & $1.0-4.6$ & $3.0-7.5$ & $0.3-2.7$ \\
Others & ND $-1,8$ & ND -5.3 & ND- 2.4 \\
\hline
\end{tabular}

${ }^{*}$ Codex Stan 210, 1999. ND - Non detectable, defined as $\leq 0.05 \%$ 
or alterations were confirmed through desmethylsterol analysis. The percentage of some desmethylsterols was over the limits found in the literature consulted. The observed alterations suggest the addition of other vegetable oils of low commercial value in Brazil, like soybean oil (sample D) and corn oils (sample E).

Due to the wide range that has been found in fatty acid and desmethylsterol profiles of sesame seed oil, the application of these parameters to uncover frauds or alterations is useful only when great differences are observed.

The evaluation of the tocopherol profile of vegetable oils could supply important information about identity and alterations of the vegetable oils studied.

\section{REFERENCES}

AOCS, American Oil Chemists' Society. 1997. Official Methods and Recommended Practices of the American Oil Chemists Society. Methods Ca-6b-53, Champaign, IL.

AOCS, American Oil Chemists' Society. 1990. Official methods and recommended practices of the American Oil Chemists' Society. Method Ce 8-89, Champaign, IL.

Antoniassi R, Souza DFS. 2001. Composição, processamento e atividade antioxidante In: Beltrão NEM, Vieira DJ. (Ed) O agronegócio do gergelim no Brasil, 327-348. Embrapa Informação Tecnológica, Brasília.

Antoniassi R, Pereira DA, Szpiz RR, Jablonka FH, Lago RC. 1998. Avaliação das características de identidade e qualidade de amostras de azeite de oliva. Braz. J. Food Technol. 1, 32-43.

Antoniassi, R, Godoy, RLO, Rosa, PM. 2002a. Esteróis de girassol e gergelim - isolamento e identificação por CGAR/EM. In: Congresso Brasileiro de Ciência e Tecnologia de Alimentos, 18, 2002a, Porto Alegre, RS. Anais. Porto Alegre: SBCTA, 2002. P.2519-2522. 1 CD-Rom.

Antoniassl, R, Godoy, RLO, Souza, DFS, Peçanha, BRB, Arriel, NHC. 2002b. Isolamento de sesamina e sesamolina de variedade de gergelim desenvolvida pela Embrapa. In: Congresso Brasileiro de Ciência e Tecnologia de Alimentos,18, Porto Alegre, RS. Anais. Porto Alegre: SBCTA, 2002. 1 CD-Rom.

AOAC, Association of Official Analytical Chemists. 1995. Official Method and Recommended Practices, Washington, D.C.

Aparicio R, Aparicio-Ruiz R. 2000. Authentication of vegetable oils by chromatographic techniques. J. Chromatogr. A 881, 93-104.

Aparicio R. 2003. Autentificación del aceite de oliva. In: Aparicio R, Harwood J. (Ed) Manual del aceite de oliva, 475-496. Madrid Vicente Ediciones, Madrid.

Aued-Pimentel S, Almeida-Gonçalves MI, Mancini-Filho J. 1993. Aplicação da espectrofotometria derivada na avaliação da qualidade do azeite de oliva. Ciênc. Tecnol. Aliment 13,121-131.

Aued-Pimentel S, Takemoto E, Rodrigues-Minazzi RS, Badolato ES. 2002. Azeite de oliva: incidência de adulterações entre os anos de 1993 a 2000. Rev. Inst. Adolfo Lutz 61, 69-75.

Badolato ESG, Almeida MEW. Pesquisa por cromatografia em fase gasosa de adulteração de chocolate. 1977. Rev. Inst. Adolfo Lutz 37, 47-58.
Badolato ESG, Duarante F, Almeida MEW, Lamardo LCA, Zenebon O. 1981. Óleos naturais: verificação de sua qualidade por cromatografia em fase gasosa. Rev. Inst. Adolfo Lutz 41, 63-70.

Bocca A, Fabiettl F, Griego D, Zunin P. 1988. Studio sulla composizione della frazione sterolica di oli di semi alimentari mediante GC capillare. Riv. Ital. Sostanze Grasse 65, 719-724.

Brigelius-Flohe R, Kelly FJ, Salonem JT, Neuzil J, Zingg JM, Azzi A. 2002. The European perspective on vitamin E: current knowledge and future research. Am. J. Clin. Nutr. 76, 703-716.

Cert A, Moreda W, Pérez-Camino MC. 2000. Chromatographic analysis of minor constituents in vegetable oils. J. Chromatogr. A 881, 131-148.

Codex Alimentarius (FAO/WHO). Codex Standard for named vegetable oils. CODEX STAN 2101999. (revision and amendments: 2003, 2005).

Coors Von U, Montag A. 1985. Proof of sesame oil. Fette Seifen Anstrichmittel. 87,177-180.

Dionisi F, Prodolliet J, Tagliaferri E. 1995. Assessment of olive oil adulteration by reversed phase high performance liquid chromatography/ amperometric detection of tocopherols and tocotrienols. J. Am. Oil Chem. Soc. 72, $1505-1511$.

Euro alert over GM seed. BBC News, UK, 18 May 2000. www.bbc.com

Firestone, D. 1999. Physical and Chemical Characteristics of Oils, Fats and Waxes. AOCS Press.

Gutfinger T, Letan A. 1974. Studies of unsaponifiables in several vegetable oils. Lipids, 9, 658-663.

Hemaltha S, Ghafoorunissa. 2004. Lignans and tocopherols in Indian sesame cultivars. J. Am. Oil Chem. Soc. 81, 467-470.

Instituto Adolfo Lutz. 2004. Normas Analíticas do Instituto Adolfo Lutz: métodos fíquico-químicos para análise de alimentos. $4^{\text {th }}$ Ed., v.1. p.21-24, 266. ANVISA, Brasília.

IUPAC. International Union of Pure and Applied Chemistry. 1992. Standard methods for analysis of oils, fats and derivatives. Method 2403. Blackwell Sci. Publ. Ltd.

Kamal - Eldin A, Appelqvist LA, Yousif G. 1994a. Lignan analysis in seed oils from four Sesamum species: comparison of different chromatographic methods. J. Am. Oil Chem. Soc., 71, 141-147.

Kamal - Eldin A, Appelqvist LA. 1994b. Variations in the composition of sterols, tocopherols and lignans in seed oils from four Sesamum species. J. Am. Oil Chem. Soc., 71, p.149-156.

Kamal-Eldin A, Appelqvist LA, Yousif G, Iskander G. 1992. Seed lipids of Sesamun indicum and related wild species in Sudan: the sterols. J. Sci. Food Agric., 59, 327-334.

Mariani C, Bellan G, Morchio A, Pellegrino A. 1999. I componenti minonori liberi ed esterificati dell'olio di oliva e dell'olio di nocciola: loro possibile utilizzo nell'individuazione di commistioni. Riv. Ital. Sostanze Grasse 76, 59-67.

Monahan FJ, Gray JI, Asghar A, Haug A, Shi B, Bukley DJ. 1993. Effect of dietary lipid and Vitamin E supplementation on free radical production and lipid oxidation in porcine muscle microsomal fractions. Food Chem. 46, 1-6.

Yermanos DM, Hemstreet S, Salleb W, Huszar CK. 1972. Oil content and composition of the seed in the world collection of sesame introductions. J. Am. Oil Chem. Soc., 49, 20-23.

Recibido: Mayo 2005 Aceptado: Noviembre 2005 